\title{
The Full Repertoire: \\ News and Press Management vs. Media Watchdog
}

\author{
Rui Alexandre Novais \\ University of Porto (Portugal) / University of Liverpool (UK)
}

Keywords: Fourth Estate, media roles, news management, press management, press scandal, spin, watchdog

\begin{abstract}
This article deals with a rare event of an overt government attempt to manage the news in response to the political crisis caused by the 2007 media coverage of the Portuguese Prime Minister's academic degree. The 'Unigate' controversy marked the end of the honeymoon period between the press and José Sócrates, as well as the first failure of the spinning and propaganda apparatus of the Cabinet. Apart from describing the full repertoire of action of both news and press management by the Prime Minister to prevent further adverse media coverage and to protect his image and reputation, this study offers critical evidence of cynical reporting and a strategic conception of politics on the part of the Portuguese media. It concludes that the contrasting roles and functioning of the press in democratic societies can coexist and that, despite not being the norm, occasionally the media rises to the challenge posed by governments and political actors and performs its watchdog role.
\end{abstract}

The role of the press in society and its functioning within democracy has been the subject of debate in literature and continues to be debated. In fact, faced with no shortage of possible roles for the media in society in extant topical studies (Blumer and Gurevitch, 1995; Christians et al., 2009; McNair, 2009; Nordenstreng, 2000), this article advances a clear categorization of such normative media roles, hereby labelled as: 'information' or 'monitorial' role, 'critical scrutiny' or 'radical' role, the 'facilitative' or 'mediator and representative' role, the 'participant' or 'advocate' role, and 'collaborative' role.

The first role, information and monitoring, refers to the process of collecting, processing and disseminating information about past, current and future events alongside a measure of comment subordinated to criteria of relevance and the ideal of objectivity (Christians et al., 2009: 125; McNair, 2009: 238). This role equates with the traditional role of professional journalism and, despite including a watchdog role on behalf of the public, it differs from the 'critical scrutiny' or 'radical' role, which goes beyond the occasional monitoring attention of the former, to exposing abuses of power with the aim of increasing the potential for a

Westminster Papers in Communication and Culture (C) 2010 (University of Westminster, London), Vol. 7(2): 51-69. ISSN 1744-6708 (Print); 1744-6716 (Online) 
fundamental change in society (Christians et al., 2009: 125).

Then, there is also the facilitative role of the press, in the sense of widening access and promoting active citizenship by way of debate and participation, which ensures that the voice of the people can be heard and helps to develop a shared framework for society (Christians et al., 2009: 126; McNair, 2009: 239). Closely related to this is the 'participant' role of the press, in which it positions itself as advocate or champion of the people, assuming a partisan position in the public debate so as to persuade the people of a particular perspective (McNair, 2009: 239-240). Lastly, the collaborative role concerns collaboration between the media and state in cases of unavoidable engagement with social events such as crisis and emergency situations: terrorism, war and disasters, to name a few (Christians et al., 2009: 127).

Generally speaking, the above-mentioned roles come into operation according to the needs experienced by participants in the political process, as well media routines, and they are dependent upon contextual factors concerning both the political and media system (Christians et al., 2009). The size of the community, the distribution of power and issues of legitimization and accountability feature among the factors which may impact upon those roles being chosen to be operational and the constraints placed on their exercise (ibid.). In the same vein, McNair (2009) raises a number of other factors comprising the pro-systemic bias of the press: competitive pressures on the media, and the 'commercialization' and 'commodification' of journalism characterized by the 'dumbing down' of the profession - referring to the increase in soft news to the detriment of hard news, and the dominance of the celebrity culture, focused on personality and image. Lastly, the same author also mentions the pernicious effect of the rise of political public relations (ibid.). Concurrently with the latter, there is the aggressive and confrontational style adopted by the press that James Fallows (1996) has called 'hyperadversarialism'. Indeed, hyperadversarialism can be seen as a sort of counterspin reaction by the press to the professionalization of political public relations, a journalism of the political process 'which accepts as a given from the outset that politicians are engaged in spin and publicity, and actively seeks to expose and deconstruct it' (McNair, 2009: 245).

Of particular interest to this study, and constituting a key strand in this journalismdemocracy relationship over recent years, is the symbiotic journalist-politician relationship (Thussu, 2000) and the contrasting notions associated with it: the 'news management' function (O’Berry, 1990; Pfetsch, 1998; Sanders et al.,1999) versus the interrelated concepts of the 'Fourth Estate' and 'watchdog role' (Demers, 
2007; Janowitz, 1975; Pinto 2008; Schudson, 1998; Sparrow, 1999; Waisbord, 2000). ${ }^{1}$

More concretely, news management can be conceived as a top-down strategic variant of public information, whereby political actors manage communication in order to influence public opinion and to control the media agenda (Blumler, 1990; Linsky, 1986). With the aim of maximizing such an influence and reducing public scrutiny, governments and political actors have more recently resorted to specialized communication consultants - spin doctors (Esser et al., 2001) - who not only monitor the media (Swanson and Mancini, 1996) but also are determined to manipulate it (Pfetsch, 1998). Such ability to manipulate what the media say about a given topic, according to an authoritative source, is achieved by twisting it to one's advantage, using a number of communication techniques to deliver the line from an angle that puts the story in the best possible light (Maltese, 1994: 215), so as to maximize the desired impact while minimizing undesired collateral effects (Esser et al., 2000; Mancini, 1999; Manheim, 1998). Moreover, a successful spin, according to Maltese, involves 'getting the media to play along by convincing them that a particular spin to the story is the correct one' (1994: 215).

Quite different from shaping and managing the media in terms of generating messages, interpreting and evaluating news, and controlling the timing of publication with the aim of influencing the political process - that is, news management - is what Hertog calls 'press management' (2000: 612-13). According to Hertog, press management implies some sort of governmental intrusion into the reporting process, involving manipulating, intimidating and seducing the mainstream media (ibid.: 613). In Western press systems, instead of influential officials resorting to direct interference in editorial policy or the content of individual articles - which is considered to be illegal or immoral pressure - press management usually involves 'soft censorship' or the use by authorities and officials of the means at their disposal (by virtue of their status) to exert direct or indirect pressure on media and journalists in order to restrict the gathering, production and distribution of information so as to secure their own political interests and ensure that their political activities escape scrutiny (Richter, 2008).

Whether in the form of news or press management, this radically challenges and restricts the ability of journalist to evaluate and criticize policy (its Fourth Estate role), as well as to scrutinize the conduct of public officers (watchdog role)

\footnotetext{
${ }^{1}$ There are other alternative propositions which are, nevertheless, outside the scope of this work, such as: the 'manufacturing consent' theory (Herman and Chomsky, 1994), which posits that the media support and serve the mainstream dominant status quo; the indexing theory, which claims that the media tend 'index' the coverage of an issue to the level of disagreement and debate (Bennett, 1990); and, lastly, the so-called 'CNN effect', when the media allegedly drive political decision-making (Gilboa, 2005; Robinson, 2002), among others.
} 
(Entman, 1989: 29, 125). Indeed, in order to function in accordance with both the Fourth Estate and watchdog roles, the media have to be able to access information, and to investigate and report free from political interference. With one difference though: whereas the former (Fourth Estate) role involves monitoring the government and publishing stories politicians would prefer to keep quiet regarding policy-making and governance abilities, the latter (watchdog) role tends to be less focused on policy issues, less concerned with the quality of the political field and more adversarial: it is prone to favour spectacle and sensation, as well as far more focused on the personal indiscretions and character of powerholders (Sabato, 1991).

Notwithstanding such a difference, the possibility of government influence over reporting, either through news or press management, is, generally speaking, difficult to prove and a highly controversial subject within Western press systems. This is even more the case if it is taken into account that news is ultimately the result of a 'three-cornered relationship between journalists, spin-doctors and politicians', in which dominance is never fixed (Low, 2005). As a result, news or press management attempts, as well as the role of press coverage in scrutinizing the government and power-holders, has been straightforwardly asserted more than it has been demonstrated, and these activities tend to escape empirical verification.

This study, however, comprises an extraordinary example, both of the disclosure of an attempt at press management as denounced by the media, and of a news management attempt overtly carried out by the governmental authorities, over a scorching political issue that threatened to undermine the Portuguese Prime Minister's political prospects and the future of the government. Therefore it constitutes a unique opportunity to make an assessment of the pragmatic performance of the press roles and the functioning of the media in democratic societies. More concretely, it aims at assessing what roles were chosen by the Portuguese media while reporting an unprecedented political scandal involving the Prime Minister, as well as the constraints placed on their exercise, namely through José Sócrates's reactive strategy to that crisis, involving spin and several distinct communicative responses.

To achieve this, this article relies primarily on a content analysis of the Portuguese daily and weekly written press coverage of the episode surrounding the academic file of the Prime Minister. The finite corpus for the press coverage analysis was drawn from the leading quality Portuguese daily and weekly newspapers: in the case of the former, Público and Diário de Notícias, and for the latter, Expresso and Sol. The choice was based upon a variety of differences between the selected newspapers. Not so much due to their political and ideological affiliations, since the Portuguese editors in general refuse to assume any orientation, but because of 
diverse degrees of editorial involvement, different journalistic routines, as well as distinct readership considerations.

A manual search of the newspapers under scrutiny was conducted by the researcher over a three-month period that seemed to be adequate for the analysis. The timeframe ranged from the day of disclosure of the story by Público (23 March 2007) until 23 June, when the story faded away after the disclosure of the lawsuit brought by the Prime Minister against António Caldeira of the blog Do Portugal Profundo. It resulted in a corpus of 160 news articles, all dealing with the investigation surrounding the Prime Minister's academic degree.

Finally, this analysis was further complemented with unscheduled interviews held with different actors from the limited universe of key respondents with direct involvement in or knowledge of the episode under analysis (Manheim and Rich, 1995: 162-4). These included the Público reporter involved in the disclosure of the story, Ricardo Dias Felner, a former Prime Minister's Press Secretary, as well as the ex-editor in chief of the Diário de Noticias.

The article is divided into four sections. First, I offer a brief background of José Sócrates' ascent to power. Second, I dwell on the circumstances surrounding the journalistic investigation and reports of the 'Unigate' episode (due to the links to the Independente University, also known as UNI), which constituted the first challenge to the Prime Minister's media communication strategy. Third, I explore the full action repertoire of both news and press management by the Prime Minister's press officers. Finally, I discuss the main findings of my study and the potential implications for the field literature.

\section{An 'Improbable' Prime Minister}

The ascent of José Sócrates to power was unusual. Following brief periods in government, first as Assistant Minister to the Prime Minister between 1997 and 1999, and then as Environment and Land Use Minister in the XIV Constitutional Government between October 1999 and April 2002, a combination of different circumstances was to conspire in his favour to catapult him into the leadership of both the Socialist Party and the country.

First, tired of politics during his second mandate, the then Prime Minister António Guterres left the government and the Socialist Party in a crisis by resigning in April 2002. This opened the opportunity for the opposition Social Democratic Party to return to government six years later, after the 17 March 2002 general election.

Shortly after the election, the new Prime Minister, José Manuel Durão Barroso, announced he was leaving the Cabinet to take the post of President of the 
European Commission. Following a period of discussion and uncertainty, the Portuguese President, Jorge Sampaio, allowed the ruling Social Democratic Party to name a successor for the place of Prime Minister. This decision was to lead to the resignation in protest of Ferro Rodrigues as Secretary-General of the Socialist Party, since he wanted the President to call anticipated elections.

As a result, José Sócrates was running unexpectedly for the party's leadership against Manuel Alegre and he was proclaimed the new Secretary-General at the Guimarães convention in September 2004, with a comfortable advantage over his opponent. In spite of the result, it was ironically said in media circles at the time that 'It would take a genius to lose the elections to Manuel Alegre' (Público, 25.04.07: 41).

In the meantime, the mandate of Durão Barroso's successor, Pedro Santana Lopes, was a brief one, marked by consecutive crises, popular protest and media criticism. This prompted the President to review his initial decision and to sack the new Prime Minister calling elections in March 2005 - an unprecedented instance in Portuguese democratic history of a president utilizing his constitutional powers to depose the government. With the Social Democratic Party discredited, the Socialist Party was back in power and Sócrates - as in the party election - again had the benefit of a comfortable majority. Once more circumstances favoured Sócrates, since a similar number of votes ( 2.5 million) had not given such a majority to António Guterres back in the 1999 elections (Público, 25.04.07: 41).

If José Sócrates was an unexpected holder of the leadership both of his party and of the government, the first communication crisis of his time in office was somewhat predictable, and to some degree an improvable one too. This is so to the extent that, on his way to both the leadership of both the party and the government, José Sócrates is said to have been a master of political communication techniques. Although Sócrates did not invent spin and the management of how media events are interpreted, he took it into another dimension in Portuguese politics in terms of professionalism and intensity (Público, 09.03.07: 46; 13.04.07: 46; Expresso, 31.03.07: 2).

At the height of his popularity, the press would, nevertheless, turn the tables on the executive's preventive spin and propaganda by prompting a political crisis centred precisely on the Prime Minister. Spin, in the end, could not save Sócrates from himself and the 'Unigate' affair threatened to undermine for good the image he had worked so hard to project. 


\section{The 'Unigate' Crisis}

At the beginning, the gist of the Público's story was whether or not the Prime Minister had presented himself as a civil engineer and how he obtained his degree. Sócrates' incomplete file - comprising unsigned, undated and unstamped documents, as well as contradictory level grades - raised such doubts.

Besides providing a full chronology of the investigation, the Público noted that, as a result of it, the Prime Minister's Cabinet had corrected his curriculum vitae (CV) on the government website (Público, 22.03.07). The first day of the coverage also included José Sócrates' censure of the newspaper for giving expression and publicity to insidious allegations based on falsity ... incited by anonymous blogs and sensationalistic media' (Público, 22.03.07: 3). The story prompted immediate interest from the newspaper's readers, to the point that it was the most consulted news item ever of its online edition $-24,000$ people accessed it in total.

Renascença, a national radio station owned by the Catholic Church, echoed the Público's front page in its news reporting, stating: 'Engineer, no ... academic degree holder, maybe' (Expresso, 31.03.07). The inter-media agenda-setting effect also initially impacted on a single television network, Televisão Independente (TVI), which addressed the issue in its 1 p.m. news but did not carry the story in the evening news. The other television and radio networks reacted with more caution and decided not to address the affair, which could be considered 'weird in view of the solid case exhibited in the reporting' (Felner, 2007). Consequently, the media coverage during the following week was more focused on the Independente University crisis rather than on the Prime Minister's CV, and was left to the exclusive reporting of the Público.

The episode gained a new breadth by the end of March when the national leading weekly newspaper joined in with Público's investigative reporting. By then, the Expresso noted that, unusually, Sócrates' diploma was signed and stamped on a Sunday and that a plan of equivalences (from a former university he had attended) had been approved and granted to him at the Independente University without the knowledge of the Scientific Council. ${ }^{2}$

Alongside the new revelations, another article on the front page of the Expresso, dealing with the Prime Minister's 'irresistible attraction to manage and control the news', was vying for attention (31.03.07). Indeed, Sócrates' press management attempts were to be transformed into a story alongside the 'Unigate' episode that would resonate with many readers. Coincidentally or not (since they belong to same media group), on the grounds that the weekly had brought new elements to

\footnotetext{
2 Allegedly the Expresso reporting was at some point fed by António Caldeira from the blog 'Do Portugal Profundo' (Felner, 2007).
} 
the episode, the television network Sociedade Independente de Comunicação (SIC) picked up the case. The Prime Minister was particularly disturbed and irritated by the fact that, despite his best efforts, the chitchat about his academic degree had made the television on the hourly SIC Notícias news service (Diário de Noticias, 01.04.07: 9).

The Público resumed the accusations concerning intimidation of the press by the Prime Minister's staff, with an opposition MP, Agostinho Branquinho, denouncing several phone calls by press secretaries and the Prime Minister to the newsroom of the newspaper. This joint endeavour aimed to convince the Público that it was a non-issue and to prevent the publication of the news investigation. Branquinho further criticized the 'threat to go to court' employed by the Prime Minister as being revealing of the 'bullying, gross attempts of manipulation, and the buying of condoning silences characteristic of the government' (Público, 04/04/07: 7).

The details of the press scandal, however, were to get worse. The Prime Minister allegedly attended third and fifth year subjects at the Independente University when the degree had only existed at the institution for two years, and consequently completed the degree before the degree itself was complete. In addition, for the remaining four subjects, Sócrates had the same lecturer in the same year, António José Morais, which prompted some doubts and further journalistic reports on such a 'dangerous' relationship (Público, 13.04.07: 2). On top of that, and based once again upon a contradiction brought up within the blog Do Portugal Profundo, apparently there were no records of any degree holders in Engineering back in 1996, contrary to what was being said by the PM (Público, 05.04.07: 4). Finally, the discussion on Sócrates' academic degree reached Wikipedia, with 70 different versions being submitted in a short time span, which prompted the enforcement of exceptional protection on the website (Público, 04.04.07).

In short, Sócrates was facing the darkest and most horribilis weeks in office. Indeed, embarrassing evidence was decimating the reputation of the Prime Minister, as well as challenging and questioning the communication efficiency of the government. The crisis was so severe that all of a sudden even his own party, the government and the Portuguese President wondered if José Sócrates' days in office were numbered (Diário de Notícias, 01.04.07: 1, 9; 08.04.07: 1, 2; and Sol, 21.04.07: 9).

\section{Failing to Prevent a Foreseeable Press Scandal ...}

Press scandals often pose a challenge to the communication team of a powerholder, especially if they deal with a question which cannot be anticipated. However, this was not the case with the story of the Prime Minister's academic degree. Indeed, allegations and rumours concerning José Sócrates' CV had been 
around for a long time in Portuguese political circles. They started back in 2005 when António Caldeira raised the issue on his blog Do Portugal Profundo, and had been quietly lingering in the blogosphere and the alternative press for some time.

Then, at the beginning of March 2007, a crisis erupted at the Independente University and its director questioned the academic degree of another co-owner of the university, Amadeu Lima Carvalho, who enigmatically claimed that his degree 'was as good as that of the Prime Minister' (Expresso, 30.03.07). Ricardo Dias Felner, one of Público's reporters, aware of the rumours both on the blogosphere and in political circles, decided to pursue the story. Felner decided to trace some of the allegations which appeared credible and check them out. Facing difficulties in accessing the files at the universities the Prime Minister had attended, the reporter decided to contact the São Bento Palace based press officers. He was used to working with them and was accustomed to 'evasive answers or silences from the Prime Minister's press secretaries'. But on this occasion an unusual nervous tension, along with the intervention of the Prime Minister, assured him that he should pursue the story (Felner, 2007).

The clues from the blog and the consequent investigations revealed enough material to go ahead with the publication of the story. According to the editor-inchief, José Manuel Fernandes, this was decided on grounds of the 'doubts on how the Prime Minister got his degree and so as to assess whether he acted in a clear, clean and legal way'. The idea, Fernandes added, 'was not to feed rumours but to finish them off' (Público, 22.03.07). Therefore, on 22 March 2007, the story on the Prime Minister's academic degree became public with Público's front-page coverage. The banner headline in that morning's edition made it clear that Sócrates had misused his academic title. Even worse, there were doubts as to how he managed to obtain it in the end.

During the general election campaign there had been allegations regarding Sócrates' sexual orientation, but the press had not seriously targeted the new Prime Minister since then. This was despite the fact that the beginning of Sócrates' mandate was marked by a series of unpopular measures on the part of the government, which were nevertheless seen as necessary to reform the country's economy and social tissue. In a blend of government activism and reform, such initiatives dared to take on the judicial and medical system, chemical companies and other major interests of the Portuguese establishment or status quo. Alongside those unpopular measures, which prompted some social unrest, the Socialist Party under Sócrates' leadership lost both the local and the Presidential elections (in the case of the latter, it was the worst result in contemporary democratic Portuguese history). 
But now the irony was inescapable. A Prime Minister who had been asking the Portuguese to get a good education and to be committed, might make history because he did not refrain from using an academic title before actually having it, and also failed to clear up doubts regarding the value of his degree.

Therefore, when the Público published a damaging report on the Prime Minister's academic parcours, it signalled the end of the honeymoon period between the press and José Sócrates. The disclosure of the episode surrounding Sócrates' academic qualifications, furthermore, posed the first challenge to the press officers' efforts to present the Prime Minister in a favourable light and to deflect potential scandals. Indeed, the press had the upper hand when the episode known as 'Unigate' was revealed, something which put all other news in the shade.

\section{... But Eventually Succeeding in Controlling the Damage}

For the first time since the beginning of Sócrates' mandate, the media had an opportunity to challenge the governmental official line by questioning and attacking the credibility of the Prime Minister. The 'Unigate' scandal was to become a game of 'Gotcha', with the journalists looking for discrepancies versus the press officers' attempts to explain in a good way the Prime Minister's messy academic file.

Sócrates started by playing defensively, trying to convince Público's reporter and editor-in-chief that it was a matter of minuscule importance based upon gossip and rumours. In his attempt to manage the news and defuse the story, the Prime Minister further resorted to the strategy of not obstructing the investigation (by both disclosing the documents and making himself available to clarify the mater) and calm denials, combined with complaints against the jaundiced view of the press. Nevertheless, Sócrates' best efforts in trying to persuade the reporters that his interpretation was more important than the facts were viewed by the press rather as a tendency to fudge the facts. The Público was neither convinced nor satisfied and continued to follow the twists and turns of the story on the Prime Minister.

As the press scandal mounted, Sócrates opted for a restrained strategy, keeping his response low key in order to prevent the story from reaching the television news agenda. When they realized that the episode had not attracted television coverage, Sócrates and his advisers opted for silence. Instead of publicizing the issue by granting importance to it, they chose to quieten the affair, hoping that it would remain at a safe distance from public knowledge. Or, at worst, within the limited realm of the 50,000 readers of Público and fringe listeners of the Renascença radio station (Felner, 2007). Curiously enough, a Prime Minister known for loudly filling the press agenda was now oddly silent. Such unusual silence and cover-up mode is 
said to have constituted, to some degree, an invitation for the press to dig further (Felner, 2007). Paradoxically, the Prime Minister also benefited from a similar uncommon silence on the matter from the opposition. Either the other political parties did not know the facts well enough to formulate a judgement on the matter, or it could also be the case that there might be some member(s) from within those parties' inner circles who were in the same circumstances as the Prime Minister and risked facing public opprobrium in the press (Diário de Notícias, 11.04.07: 10).

When other news media, and television in particular, ultimately followed took up the story, the Prime Minister was still advised to brush off embarrassing questions with brief (in the case of the SIC) or no replies. For a while, hence, it seemed that there was no sense of strategy, no coherent effort to sell the message to the press, as well as some division as to whether Sócrates should speak up or remain silent. It is arguable whether such hesitations by the Prime Minister's aides resulted from the fact that they had not decided how to defend him, while dribbling out the details, or whether they chose to pursue a safer course after seeing what the press held against him.

Whatever the reason or reasons, the evidence remains that Sócrates was under siege and the 'Unigate' episode threatened to evolve from an embarrassing political issue into a communication disaster. More important than the press frenzy and the political assault on the Prime Minister by the leader of the opposition, was the fact that Sócrates was becoming a national joke.

Since the attempts to damp down the story when it was gaining momentum did not succeed, and faced with a succession of unfavourable headlines, Sócrates realized that the issue was not going to go away. And, given that the Prime Minister's previous quiet position was becoming untenable, he now had to speak to the country and fast. Left with the dilemma of how to repair the damage, the Prime Minister's press officers seized the opportunity to engage in the art of spin.

As a transition tactic to the new approach, the Prime Minister started by arguing that he would not take a public stand before a pending decision on the closure of the Independente University by the Education Ministry was issued. ${ }^{3}$ This allowed for the São Bento Palace power-holder to gain some time and avoid being further entrapped in the interim.

But Sócrates knew by then that if he was to hold some sort of a press conference, he had to explain why he had decided to do so at such a late stage. Thus another

${ }^{3}$ This proved to be a lousy excuse since Sócrates ended up speaking before a final decision on the matter was issued. 
attempt at spin began to take shape. The Prime Minister's communication team made arrangements for a high-profile appearance at a sit-down interview to take place at the public television network. They ended up by justifying this prime-time appearance at Rádio Televisão Portuguesa (RTP) with a lame explanation related to the completion of two years in office, when in truth that anniversary had gone by unnoticed two months before.

The television interview, which attracted huge interest among the Portuguese public, ${ }^{4}$ offered the Prime Minister a unique occasion to continue to distil his spinning and propaganda. Sócrates's blame-avoidance strategy clearly aimed at bringing the scandal to a closure. Indeed, he tried almost virtually everything.

To start with, Sócrates played verbal games. Whereas he admitted that there was an understandable natural interest by the press and the public opinion on the matter of his academic degree, he still felt he was being unfairly pilloried by false accusations. Despite all the doubts surrounding his academic degree, the Prime Minister presented himself as a role model for having returned to university to finish his degree at a later stage of his life and claimed that his CV was spotless. Sócrates justified the prolonged silence on the grounds that the responsibilities inherent to the post as Prime Minister were more important than his personal image and reputation.

The 'verbal fog' employed by the Prime Minister also aimed at ensuring that his credibility and authority were not undermined by the episode, even resorting to a quote from Horace that 'those who fear the tempest end up as crawlers'. Furthermore, Sócrates also managed to compartmentalize the scandal. The spinning on this occasion was that a pupil should not be accountable for the administrative acts of his universities; and he considered having the same lecturer in four different subjects in the same year as a normal practice.

Some degree of preventive spin was also involved as far as the premeditated timed disclosure of a few additional elements was concerned, so as to defuse future charges against him. For instance, Sócrates revealed on his own initiative during the interview that he had been invited at the time to lecture at the Independente University but had refused to do so (although he did present some seminars) because this would involve a conflict of interest with his government duties. Sócrates' words would come back to haunt him afterwards, though, when the media counter-offensive proved that, in legal terms, lecturing of any kind was still incompatible with governmental functions.

\footnotetext{
${ }^{4}$ Indeed, the RTP interview had the largest TV audience for that day and for that month, with 1.6 million spectators. Curiously enough, a vast majority changed channel after the discussion of his CV was over (Público,13.04.07: 3).
} 
As a last resort, the Prime Minister endeavoured during his appearance on RTP to move the focus of the story from the accusations against him to the motivation of the accusers. In front of the cameras, nevertheless, Sócrates failed to or preferred not to identify who was behind the disclosure of the episode (Público, 12.04.07: 3). Other government cohorts and the Socialist Party apparatchiks, though, did not display the same restraint in endeavouring to transform the scandal into a weapon against the opposition (Diário de Notícias, 21.04.07: 17), or alluding to some sort of vendetta on the part of the owners of both the Expresso and the Público (Diario de Noticias, 22.04.07: 2).

Following the television interview, and in order to milk the story and neutralize the effects of the press scandal, Sócrates proposed specific measures on the matter. $\mathrm{He}$ started by initiating a discussion on the quality of academia; continued with better measures to monitor the private universities; and ended with a global reform which amounted to an attack on the public universities' historic autonomy. In an additional effort to divert attention, the well-oiled spin machine generated a wave of positive events designed to secure precious column inches and airtime for government proposals. All of a sudden, a round of ministers appeared in public, on a daily basis, to explain new government measures to the country and in the hope of relegating the 'Unigate' episode to a secondary rank in the news agenda.

So much so, that one of Público's editors, Manuel Carvalho, predicted in mid-April that the story on the Prime Minister's academic degree would soon be washed away, unless some new elements showed up (Público, 13.04.07: 46). Accordingly, a couple of months after the disclosure of the 'Unigate' scandal, it looked as if the story was fading way from the news spotlight. Nonetheless, two late developments were to resurrect the controversy and once again propelled it into the news.

First, Sócrates decided to press charges against António Caldeira, author of the blog Do Portugal Profundo. A new spin came with this move, stating that it was a personal initiative of the citizen José Sócrates, and consequently neither the press secretaries nor the Prime Minister would address the issue. A second late development concerned the discovery that the changes within Wikipedia - namely those related to the erasing of content embarrassing to the Prime Minister - had been made from a government computer (Público, 17.08.07). Such evidence, based on a new tool named 'Wikiscanner', marked the return to a no-comment strategy by the Prime Minister.

Benefiting from the fatigue of the public and the closeness of the Portuguese EU presidency, Sócrates' communication machine worked to bring the matter to a satisfactory end or, at least to stand-by mode. 
The aforementioned appraisal of the 'Unigate' scandal was revealing the Prime Minister's ability to extricate himself from being held accountable for his personal misconduct (Hood, 2002; McGraw, 1990). Sócrates achieved this by resorting to a portfolio of excuses and justifications, to avoid blame and to avoid conceding that the allegations were valid (Benoit, 1995, 1997; Bradford and Garrett, 1995; Coombs, 1999).

\section{Discussion: Failure or Success?}

It could be said that disguised media management techniques were becoming widespread under successive Portuguese governments, but only Sócrates had excelled in the art of manipulating the press. For a long time, the Portuguese media gave a free ride to Sócrates' Cabinet. To some extent this was the result of a communication strategy which had been designed to anticipate and prevent bad media coverage of the government. Above all, it had been deployed to the advantage of the Prime Minister, since this was an Executive centred on the leader. However, such strategy was incapable of preventing an acute political crisis centred precisely on the Prime Minister. Ironically enough, the press was now turning the tables on the master of spin, who was unable to prevent damaging media coverage. Indeed, the 'Unigate' scandal constituted the first attack on Sócrates and a major challenge to his ability to manage the media, as well as to set and control the agenda.

As the scandal was about to explode, the priority was to bring it to closure. Accordingly, Sócrates tried to talk Público out of the story on different grounds. He started by reverting to spin techniques, attempting to dismiss the episode as old news. Then he resorted to the justification alibi, arguing that the story was misleading and that the daily was airing a news item promoted by an alternative blog, based on rumours and a smear campaign. At the same time, Sócrates displayed some availability to cooperate with the journalistic investigations and to put forward some of the requested documents, in order to build credibility with the press.

By acting the way he did, Sócrates wanted the media organizations to exercise careful editorial judgement on whether to print the story or not, a tactic which often successfully prevents reports from being published. However, this effort to manage the news and the press, and to pre-empt the coverage, did not work out on this occasion. The Público decided to go ahead with the story about the controversy surrounding Sócrates' academic degree without buying the Prime Minister's line. And, what is worse, Sócrates' tireless efforts to prevent the publication of the episode (and the developments) prompted an unprecedented discussion about press management attempts by power-holders in Portugal, which was also to backfire against him. 
Thus, for much of this initial stage of the crisis, the Prime Minister's efforts to control the damage were perceived as clumsy by the press. In the face of the difficulty in coming up with a consistent media strategy along with a credible message, news management and spin could not save Sócrates from being castigated by the press.

When the story was published, this did not mean the press officers' role was over. Now the plan consisted in, at all costs, containing the shock wave and 'killing' the story as quickly as possible. To achieve this, both the press secretaries and the Prime Minister tried out different schemes while suitably refining their techniques.

First, they attempted to belittle the story before it made the television news banners. Silencing any reaction and confining the affair to a sole newspaper campaign, however, only ensured that the Publico would rally behind the news story. Indeed, Publico's endless excavation of the affair not only kept the issue on the news agenda but also, in the end, meant that it spread to other newspapers and television networks.

Second, after the media reporting had gained impetus, the Prime Minister resorted to a blame-avoidance strategy to restrain further adverse media coverage. Such late employment of both the denial and excuse communicative responses (as blameavoidance techniques) reached its climax during the high-profile television interview of Sócrates. In addition, government propaganda also went into action to deflect media attention from the 'Unigate' scandal. Sócrates' aides carried out this distraction manoeuvre by flooding the news agenda with positive events.

Through this case study, I made a critical assessment of a number of issues raised in the current literature. To start with, this work is revealing of a national political reality and press system usually overlooked in the literature, and constitutes an elucidating example of the coexisting roles and functioning of the press in democratic societies. More concretely, the vast majority of the mainstream Portuguese media have displayed their vulnerability to serving as organs of political propaganda by sacrificing their informational or monitoring role while accepting at face value the Prime Minister's intention to obscure evidence in public life, to treat genuine issues as marginal and to downsize the affair so as to remove it from the public agenda (Vincent, 2000). An alternative explanation for the lap-dog or selfcensorship attitude of the bulk of the Portuguese press could be the home media's determination to resist the ongoing tendency towards 'news as a spectacle' through the sensationalized exposure of petty scandals (Fallows, 1997: 57). As a result of the pressures of commercialism, and the downsizing and deskilling of newsrooms, a shift in news values had been taking place towards the reporting of spectacles and the entertainment value of events begins to take precedence over their 
political importance' (McNair, 1999: 67). Whatever the reason, it is ironic to note that, by acting in this way, the majority of the Portuguese press was playing a collaborative role with the government in a case that such an engagement could have been avoided, since the controversy surrounding the Prime Minister's CV does not amount to the usual definition of a social event equivalent to a crisis or emergency situation, as mentioned at the outset of this article.

A fringe of the press, however, has not been stripped of its ability to act as an adversary of the government. In order to perform its critical scrutiny or watchdog role vis-à-vis the government, Público (alongside Expresso, Renascença and SIC) opted to treat official pronouncements with scepticism, and was not willing to passively accept misleading claims or to defer to the Prime Minister's account of events. Against the odds, this study offers critical evidence of cynical reporting and a strategic conception of politics (Capella and Jamieson, 1997). While working with the politicians and their communication managers, some of the Portuguese media had no qualms in exposing the spin-doctoring of their interlocutors in the reporting. Nevertheless, what the exceptional nature of my study case seems to validate is that, although occasionally rising to the challenge, as Bennett and colleagues maintain, 'substantive watch-dogging does not seem to be the norm' (2008: 262).

Lastly, my article assessed the press and news management attempts, as well as the communicative response strategy to the political crisis caused by the 2007 media coverage of the Portuguese Prime Minister's academic degree. Indeed, the 'Unigate' scandal constituted an exceptionally rare event of an overt governmental attempt to manage the news. True, the public expects media to pressure politicians and power-holders and thus to fulfil their watchdog role. It is also taken for granted that media are themselves subject to pressure from government, advertisers, financial interests and others. On those occasions, the question is not whether there may or may not be any news or press management, but rather, as Knightley notes, 'the degree to which the news should be managed openly and the degree to which it should be managed subtly' (1989:438). Indeed, such operations to manipulate the media are rarely heard of by the public and normally occur behind close doors, backstage, with few people involved and through red-line telephones. This is the case because neither political actors nor the press wish to be exposed. In fact, it is damaging for a government to be targeted by the press and public finger-pointing, but it is also dangerous for an editor to acquiesce to government interference in news coverage since, if this was found out, he would become vulnerable to pressure and lose all credibility.

Against this background, the 'Unigate' scandal is also an invaluable example comprising the full action repertoire of both news and press management by the Prime Minister's press officers. Unable to hide his own spin and caught 
unprepared without a contingency plan for a rapid crisis response in reaction to the early warnings of a potential problem, the Prime Minister did eventually manage to put into stand-by mode a scandal that had dragged on in the press for months. He minimized the damage by spinning a new line, resorting to plausible deniability and deflecting attention elsewhere through the 'de-thematization technique' - shifting from substantial issues to other aspects of the problem. The forthcoming Portuguese EU presidency, alongside the regional elections in Lisbon and the Madeleine McCann disappearance, which also vied for media attention, further moved the news focus away from the Prime Minister.

The saga about the Prime Minister is at the moment dormant but not over since the author of the blog has promised to disclose other skeletons harboured by Sócrates. Only time will confirm whether the Portuguese media will consent to a second honeymoon with Sócrates or if, from now onwards, it will display a degree of distrust in the government and in the Prime Minister in particular. The pressure of events will also help to show whether Sócrates lost this round with the press or if he gained more communication ability to deal with crisis situations.

\section{References}

Bennett, W.L. (1990) 'Toward a theory of press state relations in the United States', Journal of Communication 40(2): 103-25.

Bennett, W.L., R.G. Lawrence and S. Livingston (2008) When the Press Fails: Political Power and the News Media from Iraq to Katrina, Chicago: University of Chicago Press.

Benoit, W. L. (1997) Image repair discourse and crisis communication. Public Relations Review, 23(2):177-186.

Benoit,W. L. (1995) Accounts, excuses, and apologies: A theory of image restoration discourse. Albany: State University of New York Press.

Blumler, J. (1990) 'Elections, the media and the modern publicity process', in M. Ferguson (ed.) Public Communication - The New Imperatives: Future Directions for Media Research, London: SAGE, pp. 101-13.

Blumer, J. and M. Gurevitch (1995) The Crisis of Public Communication, London: Routledge.

Bradford, J. L., \& Garrett, D. E. (1995). The effectiveness of corporate communicative responses to accusations of unethical behavior. Journal of Business Ethics, 14(11): 875-892.

Cappella, J.N. and K.H. Jamieson (1997) Spiral of Cynicism: The Press and the Public Good. New York: Oxford University Press.

Christians, C.G., T. Glasser, D. McQuail, K. Nordenstreng and R. White (2009) Normative Theories of the Media: Journalism in Democratic Societies, Chicago: University of Illinois Press.

Coombs, W. T. (1999). Ongoing Crisis Communication. Thousand Oaks, CA: Sage. 
Demers, D. (2007) History and Future of Mass Media: An Integrated Perspective, Cresskill, NJ: Hampton Press.

Entman, R. (1989) Democracy without Citizens: Media and the Decay of American Politics, New York: Oxford University Press.

Esser, F., C. Reinemann and D. Fan (2001) 'Spin doctors in the United States, Great Britain, and Germany: metacommunication about media manipulation', Harvard International Journal of Press/Politics 6(1): 16-45.

Esser, F., C. Reinemann and D. Fan (2000) 'Spin doctoring in British and German election campaigns: how the press is being confronted with a new quality of political PR', European Journal of Communication 15(2): 209-39.

Fallows, J. (1997) Breaking the News: How the Media Undermine American Democracy, 2nd edn. New York: Vintage.

Fallows, J. (1996) Breaking the News, New York: Pantheon.

Gilboa, E. (2005) 'The CNN effect: the search for a communication theory of international relations', Political Communication 22: 27-44.

Herman, E. and N. Chomsky (1994) Manufacturing Consent: The Political Economy of the Mass Media, London: Vintage.

Hertog, J.K. (2000) 'Elite press coverage of the 1986 US-Libya conflict: a case study of tactical and strategic critique', Journalism Quarterly 77(3): 616-27.

Hood, Christopher (2002) The Risk Game and the Blame Game, Government and Opposition 37(1):15-37.

Janowitz, M. (1975) 'Professional models in journalism: the gatekeeper and the advocate', Journalism Quarterly 52(4): 618-26.

Knightley, P. (1989) The First Casualty. From Crimea to Vietnam: The War Correspondent as Hero, Propagandist and Myth Maker, London: Pan Books.

Linsky, M. (1986) Impact: How the Press Affects Federal Policymaking, New York: Norton.

Low, Eric (2005) The Media and the Political Process, London:Sage.

Maltese, J.A. (1994). Spin Control, 2nd edn. Chapel Hill: University of North Carolina Press.

Mancini, P. (1999) 'New frontiers in political professionalism', Political Communication 16(3): 231-45.

Manheim, J.B. (1998) 'The news shapers: strategic communication as a third force in news making', in D. Graber, D. McQuail and P. Norris (eds.) The politics of news, the news of politics, Washington, DC: CQ Press, pp. 45-73.

Manheim, J. B. and Rich, Richard C. (1995) Empirical political analysis: research methods in political science, New York: Longman.

McGraw, Kathleen (1990) Avoiding Blame: An experimental Investigation of Political Excuses and Justifications, British Journal of Political Science 20 (1):119-142.

McNair, B. (2009) 'Journalism and democracy', in K. Wahl-Jorgensen and T. Hanitzsch (eds.) Handbook of Journalism Studies, New York: Routledge.

McNair, B. (1999) An Introduction to Political Communication, London: Routledge. 
Nordenstreng, K. (2000) 'The structural context of media ethics', in B. Pattyn (ed.) Media Ethics: Opening Social Dialogue, Leuven: Peeters, pp. 81-98.

O'Berry, N. (1990) Foreign Policy and the Press: An Analysis of The New York Times' Coverage of U.S. Foreign Policy, London: Greenwood Press.

Pfetsch, B. (1998) 'Government news management', in D. Graber, D. McQuail and P. Norris (eds.) The Politics of News, The News of Politics, Washington, DC: CQ Press.

Pinto, J. (2008) 'Muzzling the watchdog: the case of disappearing watchdog journalism from Argentine mainstream news', Journalism 9(6): 750-74.

Richter, A. (2008) 'Post-Soviet perspective on censorship and freedom of the media: an overview', International Communication Gazette 70(5): 307-24.

Robinson, P. (2002) The CNN Effect: The Myth of News, Foreign Policy and Intervention. New York: Routledge.

Sabato, L.J. (1991) Feeding Frengy: How Attack Journalism Has Transformed American Politics, New York: Free Press.

Sanders, K., T. Bale and M.J. Canel (1999) 'Managing sleaze: prime ministers and news management in conservative Great Britain and Socialist Spain', European Journal of Communication 14(4): 461-86.

Schudson, M. (1998) The Good Citizen: A History of American Public Life, New York: Free Press.

Sparrow, B.H. (1999) Uncertain Guardians: The News Media as a Political Institution, Baltimore, MD: Johns Hopkins University Press.

Swanson, D. and P. Mancini (1996) Politics, Media and Modern Democracy, Westport, CT: Praeger.

Thusu, D.K. (2000) 'Legitimizing "humanitarian intervention"? CNN, Nato and the Kosovo crisis', European Journal of Communication 15(3): 345-61.

Vincent, R.C. (2000) 'A narrative analysis of US press coverage of Slobodan Milosevic and the Serbians in Kosovo', European Journal of Communication 15(3): 312-44.

Waisbord, S. (2000) Watchdog Journalism in South America: News, Accountability and Democracy. New York: Columbia University Press.

\section{Interviews}

Felner, Ricardo Dias, reporter of the Público, by telephone, 24 August 2007.

Laranjeiro, Miguel, Prime Minister's Press Secretary (1995-2000), in Guimarães, 10 September 2006.

Resendes, Mário Bettencourt, editor-in-chief of the Diário de Notícias, at the Diário de Noticias headquarters in Lisbon, 30 June 2005. 